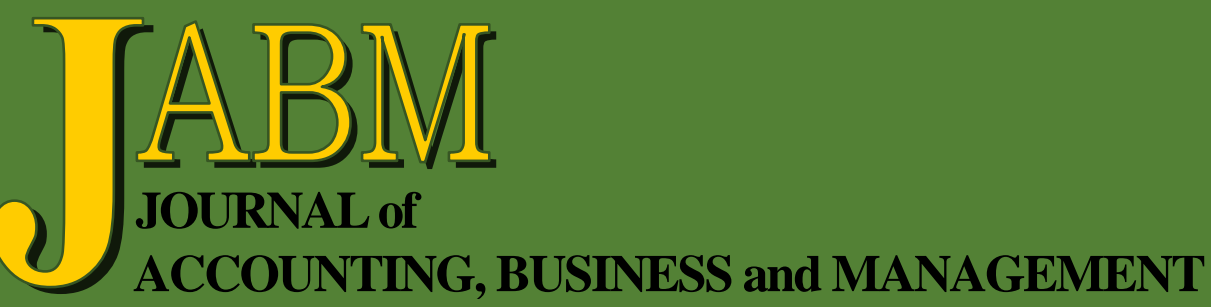

Audit Fee Premium for Industry Specialization: A Developed Country Perspective

Muhammad Shahin Miah

Socio-Demographics Characteristics on Investment Objectives of Individual Investors: Empirical Study in Indonesia

Nevi Danila, Zaiton Ali, Bunyamin and Marlinda D. K.

Dynamic Inflation and Economic Growth Nexus in Bangladesh

Md. Nezum Uddin

Voice of the Customer: Creating Client Centered Cultures in Accounting Firms for Retaining Clients and Increasing Profitability Leisa Gill, Vikkie McCarthy and David Grimmett

Rating the Credit Raters

A. Seetharaman, Nitin Patwa and Shriram Nagarajan 


\title{
Audit Fee Premium for Industry Specialization: A Developed Country Perspective
}

\author{
Muhammad Shahin Miah*
}

\begin{abstract}
This paper examines the effects of industry specialization (city-level, nationallevel, and joint-level) on audit pricing in the Australia. By using Australian Stock Exchange (ASX) listed companies, this study documents that auditors who are industry specialists at both city-and national-level charge significantly higher audit fees compare to those auditors who are specialists either only at city-level or only at national-level industry specialist. However, in further analysis, this study documents that firms who are city-level industry specialists they charge relatively higher audit fees than nationallevel industry specialists, which is consistent with prior research on audit fee premiums studies concentrated in Australia. The greater audit fees charged by city-level industry specialists auditors are possibly attributed to recent changes in accounting regulations environment in Australia (e.g., mandatory adoption of IFRS). Such a significant shift in financial reporting environment due of IFRS adoption can affect audit expertise which may be reflected in this study. This study findings are robust in a set of alternative tests following prior research.
\end{abstract}

Keywords: audit fee, industry specialization, brand premium, auditor choice, IFRS adoption, Big 4 auditor, audit quality.

\section{INTRODUCTION}

In this study, I investigate the effects of industry specialization (e.g., at city-level, national-level, and joint level) on audit fess in Australia. This is because in Australia prior research shows that city-level industry specialist auditors charge higher audit fees compared to national-level industry specialist auditors. For instance, Ferguson et al. $(2003$; 2006) document that industry specialists at both city-level and one of the top 2 firms nationally industry specialists charge premium audit fees compared to nonindustry specialist auditors do. Their analysis of audit fees was based on data 1998 which was much earlier of a big move of Australia to IFRS adoption. Australia has mandatorily adopted all international accounting standards (IASs) and international financial reporting standards (IFRSs) since 2005 in line with the United Kingdom. Australia is the first country outside the European Union (EU) which adopted all IFRS/IASs at the same time the UK adopted in 2005. It is rational and natural question, whether auditors face any challenges with IFRS/IASs, or charge higher audit fees to compensate their additional efforts required after IFRS adoption. Prior research shows that IFRS involves judgement, management discretionary choices, thereby results in in formation risks or audit risks (Ettredge et al., 2014). To deal with complexity (e.g., fair value), auditors who are experts (like KPMG, PWC, Deloitte, and Earnst and Young) may charge higher audit fees compared to other auditors do as because of their expertise, and differentiated audit quality.

\footnotetext{
* Assistant Professor of Accountancy, Department of International Business, University of Dhaka, Dhaka-1000, Bangladesh. E-mail: shahin11071@gmail.com or mshahin@du.ac.bd.
} 
Using a sample of 1085 Australia listed companies, this study documents that auditors who are specialist at both city-and national-level, they charge significantly higher audit fees compared to auditors who are either only city or only national-level industry specialist auditors. However, there is a little difference in fee premium between city-level industry specialist and national-level industry specialist auditors.

Consistent with prior research, this research also document that the above findings do not change when we run sensitivity analysis by excluding firms in two small cities (e.g., Brisbane and Adelaide) in Australia. ${ }^{1}$

This study contributes to an understanding of audit pricing by industry specialists in a number of ways. First, this study adds to current knowledge about the pricing differences between city-level and national-level. Prior research focuses only on top two national firms, whereas, current study does not make such rigid classification. Rather this study calculates nationally industry specialists which will extend the prior studies in this respect. Second, this study extends the literature of audit fees especially from Australian perspective (e.g., De George et al., 2013). Third and finally, this study provides an evidence of changes in audit fees just after adoption of international accounting standards which gives us avenue to investigate further what extent of audit fees can be attributed to IFRS adoption.

The next section develops the study's hypothesis and explain why industry specialization is important and the differences between city-level and national-level expertise. Section III presents research methodology including sample selection procedure, measurement of ISP, and research design. Section IV presents main test results. Section V concludes the study.

\section{LITERATURE REVIEW AND HYPOTHESIS DEVELOPMENT}

A substantial prior research has been conducted relating to audit fee premium charged either by Big 4/5/8 auditors (e.g., Basioudis \& Francis, 2007; Lawrence et al., 2011) or industry specialists auditors (e.g., Craswell et al., 1995; DeFond et al., 2000; Ferguson \& Stokes, 2002; Ferguson et al., 2003; Francis et al., 2005; Ferguson et al., 2006; Basioudis \& Francis, 2007; Hua-Wei et al., 2007; and Reichelt \& Wang, 2010).

Craswell et al. (1995) investigate the confounding effect between brand name reputation $(\mathrm{Big} \mathrm{N})$ and industry specialisation. Using a large sample of Australian listed firms, they document that industry specialist Big N auditors earn, on overage, a 34\% premium over non-specialist Big $\mathrm{N}$ auditors. ${ }^{2}$ They contend that in industries having specialist auditors, non-specialist Big $\mathrm{N}$ auditors are regarded as equivalent to non-Big $\mathrm{N}$ firms who are also non-specialists. Consequently, specialist auditors should be a more clearly differentiated proxy for audit quality than Big 4. Furthermore, auditors' knowledge of their clients' industry is a prerequisite in today's complex and interconnected global economy (Bell et al., 1997; Miah, 2019) and affects auditors' judgements and assessment of risk. This in turn improves their performance and helps them to anticipate possible misstatements, which ultimately improves audit quality (Taylor, 2000; Low, 2004). DeFond et al. (2000) examine the difference in audit fees

\footnotetext{
${ }^{1}$ Consistent with Ferguson et al. (2003, 2006), the present study is based on 5 Australian big cities (e.g., Perth, Melbourne, Sydney, Adelaide, and Brisbane). Among 5 cities, Brisbane and Adelaide has least number of audit clients. I also re run my audit fee regression excluding these two small cities to see if there is any outlier effect or not. My results do not change after doing such analysis which is consistent with prior research.

${ }^{2}$ Big N indicates Big 8 audit firms. Craswell et al. (1995) conducted their study when the Big 8 audit firms were still recognised as such in the audit market.
} 
between Big 6 and non-Big 6 auditors for publicly listed companies in Hong Kong. Using a sample of 348 companies, they document that Big 6 auditors earn 37 percent higher audit fees compared to non-Big 6 auditors. In addition, they find that industry specialists as well Big 6 auditors earn 29 percent higher than non-specialists Big 6 audit firms. In detailed analysis they show that local firm Kwan Wong Tan \& Fong does not earn any premium as because of their general brand or industry specialisation in China.

Francis et al. (2005) examined the audit pricing for locally and nationally specialist auditors in the U.S. for the period 2000-2001 as the U.S. mandated audit fees disclosure beginning from 2000. Using audit fee framework of Ferguson et al. (2003), they find that Big 5 auditors enjoy 19 percent premium when they are specialists at both city-level and national-level. They also show that there is no premium for auditors who are only national-level industry specialists. However, they did not find any conclusive findings regarding brand premium who are just only city-level industry specialists. Another study, Cahan et al. (2011) contend that there are two types of ISPs - one being product specialists and the other being cost specialists. The former competes using a product specialization strategy, by differentiating their product from competitors in order to build barriers and reduce head-to-head competition. This strategy stresses uniqueness rather than price discount. Therefore, product specialists would be associated with higher audit fees. However, the latter use a cost minimization strategy, related to fee discounts. Industry specialists competing on product differentiation, as opposed to price competition, tend to focus on industries where client firms are less homogeneous, more complex, or possess unique accounting issues(e.g., GAO, 2003; 2008). Reconciliation between domestic GAAP and IFRS results in a larger adjustment for firms with greater exposure to certain business activities. When accounting standards get complex, auditors need to utilize their industry product specialization and extend greater effort.

Hua-Wei et al. (2007) replicated Casterella et al. (2004) study by investigating the impact of industry specialization on audit fees in the U.S. audit market. Consistent with Casterella et al. (2004), they find that there is a premium audit fees for industry specialization but only for small client segment. They did not find any fee premium for large client segment which makes the later study value worthy. More specifically, Casterella et al. (2004) conducted their research using survey based data as till then there was no quantitative data available. In contrast, Hua-Wei et al. (2007) used real audit fee data as audit fee was available since 2000 in the U.S. They also suggest that the fee increase can also be attributed to enactment of Sarban-Oxley Act.

Similarly, the present study also investigates and extend the results of (Ferguson \& Stokes, 2002; Ferguson et al., 2003; and Ferguson et al., 2006) studies to see whether there is any change regarding fee premium for either city-level or national-level industry specialization as there was a significant change in accounting practices in Australia. For instance, Australia adopted IFRS in 2005 which has significant impact on accounting practice and financial reporting which may have affected audit profession. So, it is worthwhile to re-examine the fee premium scenario in Australia. Second, the data used by Ferguson et al. $(2003$; 2006) was relatively old and it was before IFRS adoption. Considering the limitations of above studies, and timeliness of current studies, I do believe this study will enrich current literature of audit fees studies and brand premium related to industry specialization. 


\section{RESEARCH DESIGN AND SAMPLE DETERMINATION}

\subsection{Sample}

I select all ASX listed companies which have filed annual reports for fiscal period of 2005-2006. As most of companies, in Australia, follows July-June as their accounting reporting period, firms who submitted annual reports for 2005-2006 are considered in this study. Required data to calculate control variables are collected from DataStream and audit related information is collected from Securities Industry Research Centre of Asia-Pacific (SIRCA). A total 1587 companies are available as listed companies as on June 30, 2006. After deleting all firms which have either data availability issues, or delisting issues, or currency changes, I find only 1122 firms. As this study only focus on five big cities in Australia (such as, Adelaide, Brisbane, Melbourne, Perth, and Sydney) following Ferguson et al. (2003; 2006), which gives final sample of 1085 companies. Table 1 provides sample breakdown sector wise in detail.

\subsection{Measurement of Industry Specialization}

Following the approach of Ferguson et al. (2003) and Francis et al. (2005), I measure ISP as the audit firm who has the largest market share (i.e. based on audit fees) in the same industry, because the auditor with dominant presence in the industry is likely to possess specialist expertise as a result of superior industry knowledge and more experienced human resources. Using audit fees to measure market share is also consistent with industrial organization literature which measures market share using industry output (DeFond et al., 2000).

Table 1

Sample Breakdown Industry Wise

\begin{tabular}{clcc}
\hline No. & \multicolumn{1}{c}{ Sector } & Number of Firms & Percentage \\
\hline 1 & Automobiles and Components & 10 & $1 \%$ \\
2 & Capital Goods & 63 & $6 \%$ \\
3 & Commercial \& Professional services & 6 & $1 \%$ \\
4 & Commercial Services \& Supplies & 37 & $3 \%$ \\
5 & Consumer Durables and Apparel & 15 & $1 \%$ \\
6 & Consumer Services & 32 & $3 \%$ \\
7 & Diversified Financials & 34 & $3 \%$ \\
8 & Energy & 130 & $12 \%$ \\
9 & Food and Staples Retailing & 4 & $0 \%$ \\
10 & Food, Beverage and Tobacco & 25 & $2 \%$ \\
11 & Health Care Equipment and Services & 46 & $4 \%$ \\
12 & Household and Personal Products & 3 & $0 \%$ \\
13 & Insurance & 5 & $0 \%$ \\
14 & Materials & 360 & $33 \%$ \\
15 & Media & 36 & $3 \%$ \\
16 & Miscellaneous & 3 & $0 \%$ \\
17 & Pharmaceuticals and Biotechnology & 59 & $5 \%$ \\
18 & Real Estate & 38 & $4 \%$ \\
19 & Retailing & 31 & $3 \%$ \\
20 & Semiconductors & 3 & $0 \%$ \\
21 & Software and Services & 65 & $6 \%$ \\
22 & Technology Hardware & 25 & $2 \%$ \\
23 & Telecommunications & 17 & $2 \%$ \\
24 & Transportation & 17 & $2 \%$ \\
25 & Utilities & 21 & $2 \%$ \\
\hline & & 1085 & $\mathbf{1 0 0} \%$ \\
\hline
\end{tabular}


Other measures of ISPs (such as Client size and number of clients) may be suitable for settings where audit fee disclosures are unavailable. ${ }^{3}$ Audit fees can capture auditors' efforts better than other ISP measurements as audit fees are a function of client size, complexity and riskiness (Audousset-Coulier et al., 2016).

ISPs are measured at city- and national-level respectively. I also identify joint ISPs as specialists at both city- and national-levels. To this end, I use the following procedure to identify ISPs. First, the location of audit firms is identified for all sample companies. 1085 companies are found to have auditors locating in five big cities in Australia, including Adelaide, Brisbane, Perth, Melbourne and Sydney. Then, I calculate the total audit fees of each audit firm in each industry and in each of the five cities. The audit firm with the highest audit revenue in a particular industry and a particular city is ranked as a city-level ISP. I repeat this procedure to recognize each national-level ISP with the highest revenue in a particular industry in a particular year nation-wide. Lastly, joint ISPs are identified as audit firms with both city- and national-level industry specialist status.

\subsection{Research Design}

To test my proposition, the following audit fee regression model is used:

\section{LnAFEE $=B_{0}+B_{1} A U D I T \_I S P+B_{2} \operatorname{LnNAS}+B_{3} O P I N I O N+B_{4} \operatorname{Ln}(A S S E T S)$ $+\mathrm{B}_{5} \mathrm{DEBT}+\mathrm{B}_{6} \mathrm{REC}+\mathrm{B}_{7} \mathrm{INV}+\mathrm{B}_{8} \mathrm{ACCR}+\mathrm{B}_{9} \mathrm{ROA}+\mathrm{B}_{10} \mathrm{LOS}$ $+\mathrm{B}_{11} \mathrm{QUICK}+\mathrm{B}_{12} \mathrm{SUB}+\mathrm{B}_{13}$ GEOSUB $+\mathrm{B}_{14}$ INDUSTRYFIXED EFFECTS+e}

Where:

AUDIT_ISP is the variable of interest representing auditor industry specialization and is proxied by three measures including:

1) City-level ISP;

2) National-level ISP; and

3) Joint ISP for auditor being both city- and national-level ISP.

LnNAS = natural log of total non-audit service fees paid to external auditors;

OPINION $=1$ for modified opinion, otherwise 0 ;

LnASSETS $=$ natural log of total assets under AGAAP;

DEBT = ratio of long-term debt to ending total assets;

REC = ratio of total receivables to ending total assets;

INV = ratio of total inventory to ending total assets;

ACCR = absolute value of accruals (computed as difference between net income and cash flow from operations) scaled by ending total assets;

ROA = ratio of net profit after tax to ending total assets;

QUICK = ratio of current assets to current liabilities;

LOSS $\quad=1$ if the firm reported loss in the sample period, otherwise equal to 0 ;

SUB = natural $\log$ of 1 plus the number of subsidiaries; and

GEOSUB $=$ natural $\log$ of 1 plus the number of foreign subsidiaries.

Other variables are as defined before. I expect a positive and significant $\beta_{3}$ if hypothesis 2 is supported.

\footnotetext{
${ }^{3}$ For example, audit fee disclosures did not become enforced until 2000 in the United States (Audousset-Coulier et al., 2016). Audousset-Coulier et al. (2016) investigate the validity of ISP measurements; they find that audit fee is the significant determinant of ISP measurement compared to other available ISP measurements.
} 


\section{MAIN TEST RESULTS}

\subsection{Descriptive Statistics and Correlations}

Table 2 Panel A presents descriptive statistics for whole sample. The mean value of LnAFEE in 2006 is 4.2684 where mean value of LnAFEE was 3.82 in Ferguson et al. (2003) study, which suggests there is a substantial increase in audit fees charged by auditors. Of 1085 firms, 532 firms are audited by Big 4 auditors. Mean value of LnAFEE, based on sample audited by only Big 4, is 4.98 whereas Ferguson et al. (2003) shows it is 4.16. Overall, mean value in both cases found to have increased significantly in Australia. The mean value of CITY_ISP is higher than the mean value of NATIONAL_ISP which is consistent with prior studies. Surprisingly, the mean value of JOINT_ISP is not showing higher value though it is expected. Similar scenario is prevailing when we use combined model considering city-level ISP but not nationallevel or national-level ISP but not city-level ISP situation. Then mean (median) value of LnAssets is 10.353 (10.095) which is steady over the periods which is highly consistent in Australian audit fee market. Panel B, Table 2, reports Pearson correlations. There is a strong and positive correlation between LnAFEE and CITY_ISP, NATIONAL_IPS, JOINT_ISP, CITYNOT NATIONAL_ISP. But relation between LnAFEE and NATIONALNOTCITY_ISP is positive but not statistically significant. For other control variables, LnAFEE is positively and significantly associated with LnNAS, DEBT, LnASSETS, INV, ROA, SUB, and GEOSUB. On the other hand, LnAFEE is negatively associated with LOSS which is consistent with prior Australian audit fee studies (e.g., De George et al., 2013).

\subsection{Regression Analysis Results}

Table 3 reports the OLS regression results of industry specialization and audit fees. Model 1 shows the association between city-level industry specialization and audit fees. Coefficient of CITY_ISP is $0.356(t=7.62 ; \mathrm{p}<0.00001)$, which indicates that citylevel ISP auditors charge significantly higher audit fees compared other non-specialist auditors do, which is consistent with prior research by Ferguson et al. (2003). Model 2, also shows the impact of national-level industry specialization on audit fees. Coefficient suggests that national-level industry specialist auditors also charge higher audit fees. When we compare Model 2 with Model 1, we see city-level ISP auditors charge higher audit fees than national-level ISP auditors which confirms prior research findings. In model 3, I investigate whether joint ISP (specialist at both city-and national-level) auditors earn any premium audit fees. Coefficient of JOINT_ISP is positive and statistically significant $(\beta=0.421 ; t=6.84$; and $p<0.001)$, which suggests that joint specialist auditors earn premium audit fees which is higher than individually either citylevel or national-level industry specialist auditors. Following Ferguson et al. (2003), I run the model 4 which combines 3 different specifications of variables of interest (e.g., city but not national-level ISP, national but not city-level ISP, and JOINT_ISP) to see whether there is any deviation from the above 3 models. Coefficients of all three variables are showing positive and significant association with LnAFEE. Similarly, citylevel ISP but not national-level ISP auditors charge higher audit fees compared to national-level but not city-level ISP which confirms the findings of first two models (model 1 and model 2). The above finding is inconsistent with Ferguson et al. (2003), because they show that city-level ISP but not national-ISP or national-ISP but not cityISP do not enjoy any brand premium. They document that auditors who are specialist at both level (national \#1 or \#2 and city \#1) enjoy brand premium. The possible reasons for inconsistent results can be explained as follows, such as, 1) national-level 
ISP auditors also develop their expertise in their audit scope or increase their competence level which helps them to attract more clients, thereby results in higher audit fees, 2) as mentioned earlier, Australia has experienced with a big movement with accounting regulations (i.e., mandatory adoption of IFRS since 2005). Prior research shows that IFRS adoption increase audit complexity which increases auditors' risk and reputation risks, thereby results in higher audit fees (De George et al., 2013; Miah, 2017). Miah (2017) documents that IFRS, in Australia, involves complexity which increases auditors' tasks. He found that several IFRS standards are relatively more complex than other IFRS standards. He investigated and found that individual IFRS involves complexity and such complexity affects auditors' fees. Another plausible reason for higher audit fees charged by national-level ISP is the development of auditors' expertise which may be required to reduce possible litigation risks to cope up the changes happen due to IFRS adoption.

Table 2

Descriptive Statistics

\begin{tabular}{|c|c|c|c|c|c|c|c|c|}
\hline \multicolumn{9}{|c|}{ Panel A: Descriptive statistics } \\
\hline Variable & $\mathbf{N}$ & Mean & $\begin{array}{l}\text { Std. } \\
\text { Dev. }\end{array}$ & $\begin{array}{c}\text { Medi- } \\
\text { an }\end{array}$ & $\begin{array}{c}\text { Skew- } \\
\text { ness }\end{array}$ & $\begin{array}{c}\text { Kurto- } \\
\text { sis }\end{array}$ & Min & $\operatorname{Max}$ \\
\hline LnAFEE & 1085 & 4.268 & 1.318 & 4.072 & 0.698 & 3.130 & 1.950 & 8.107 \\
\hline CITT_ISP & 1085 & 0.236 & 0.425 & 0 & 1.238 & 2.532 & 0.000 & 1.000 \\
\hline NATIONAL_ISP & 1085 & 0.180 & 0.385 & 0 & 1.660 & 3.756 & 0.000 & 1.000 \\
\hline JOINT_ISP & 1085 & 0.118 & 0.323 & 0 & 2.369 & 6.610 & 0.000 & 1.000 \\
\hline $\begin{array}{l}\text { CITY_ISP NOT } \\
\text { NATIONAL_ISP }\end{array}$ & 1085 & 0.119 & 0.000 & 0.324 & 2.355 & 6.546 & 0 & 1 \\
\hline $\begin{array}{l}\text { NATIONAL_ISP } \\
\text { NOT CITY_ISP }\end{array}$ & 1085 & 0.063 & 0.000 & 0.242 & 3.609 & 14.023 & 0 & 1 \\
\hline LnNAS & 1085 & 2.623 & 2.142 & 2.681 & 0.246 & 2.022 & -0.369 & 7.555 \\
\hline OPINION & 1085 & 0.141 & 0.348 & 0 & 2.063 & 5.256 & 0.000 & 1.000 \\
\hline LnASSETS & 1085 & 10.353 & 2.203 & 10.095 & 0.443 & 3.048 & 5.155 & 16.082 \\
\hline DEBT_06 & 1085 & 0.095 & 0.159 & 0.002 & 2.071 & 7.447 & 0.000 & 0.789 \\
\hline REC_06 & 1085 & 0.148 & 0.347 & 0.052 & 6.380 & 49.172 & 0.000 & 2.938 \\
\hline INV_06 & 1085 & 0.060 & 0.110 & 0.002 & 2.219 & 7.512 & 0.000 & 0.501 \\
\hline ACR_06 & 1085 & 0.238 & 0.633 & 0.072 & 5.541 & 36.099 & 0.001 & 4.716 \\
\hline ROA & 1085 & -0.277 & 0.838 & -0.034 & -4.389 & 25.430 & -5.669 & 0.399 \\
\hline LOSS & 1085 & 0.549 & 0.498 & 1 & -0.198 & 1.039 & 0.000 & 1.000 \\
\hline QUICK_06 & 1085 & 5.423 & 10.092 & 1.66 & 4.013 & 22.147 & 0.000 & 68.668 \\
\hline FORSUBS_06 & 1085 & 0.936 & 0.363 & 0.693 & 0.667 & 3.026 & 0.000 & 1.792 \\
\hline TOTSUBS_06 & 1085 & 0.923 & 0.372 & 0.693 & 0.841 & 3.304 & 0.000 & 1.946 \\
\hline YE & 1085 & 0.099 & 0.298 & 0 & 2.693 & 8.250 & 0.000 & 1.000 \\
\hline
\end{tabular}

Insert Panel B: Pearson Correlation Statistics here 
Table 3

Ordinary Least Square (OLS) Regression Analysis Showing Difference Brand Premium

\begin{tabular}{|c|c|c|c|c|c|}
\hline & $\begin{array}{c}\text { City-Level } \\
\text { Industry } \\
\text { Specialization }\end{array}$ & $\begin{array}{l}\text { National- } \\
\text { Level } \\
\text { Industry } \\
\text { Specializa- } \\
\text { tion }\end{array}$ & $\begin{array}{l}\text { Both City and } \\
\text { National- } \\
\text { Level } \\
\text { Industry } \\
\text { Specialization }\end{array}$ & $\begin{array}{l}\text { Combined } \\
\text { Model (City } \\
\text { but not Nati- } \\
\text { onal, Nati- } \\
\text { onal but not } \\
\text { City-Level) } \\
\end{array}$ & $\begin{array}{c}\text { Test } \\
\text { Excluding } \\
\text { Brisbane } \\
\text { and } \\
\text { Adelaide }\end{array}$ \\
\hline & (1) & (2) & (3) & (4) & (5) \\
\hline VARIABLES & LnAFEE & LnAFEE & LnAFEE & LnAFEE & LnAFEE \\
\hline Constant & $\begin{array}{l}0.402 \\
{[1.62]}\end{array}$ & $\begin{array}{c}0.457^{*} \\
{[1.74]}\end{array}$ & $\begin{array}{c}0.450^{*} \\
{[1.72]}\end{array}$ & $\begin{array}{c}0.473^{*} \\
{[1.91]}\end{array}$ & $\begin{array}{c}0.470^{*} \\
{[1.67]}\end{array}$ \\
\hline CITY_ISP & $\begin{array}{c}0.365 * * * \\
{[7.62]}\end{array}$ & & & & \\
\hline NATIONAL_ISP & & $\begin{array}{c}\mathbf{0 . 3 5 6 * * *} \\
{[6.68]}\end{array}$ & & & \\
\hline CITY_ISP but not & & & & $0.301 * * *$ & $0.300 * * *$ \\
\hline NATIONAL_ISP & & & & [5.19] & [4.55] \\
\hline NATIONAL_ISP & & & & $0.276 * * *$ & $0.267 * * *$ \\
\hline but not CITY_ISP & & & & [3.12] & [2.69] \\
\hline JOINT_ISP & & & $\begin{array}{c}\mathbf{0 . 4 2 1} * * * \\
{[6.84]}\end{array}$ & $\begin{array}{c}0.502 * * * \\
{[7.79]}\end{array}$ & $\begin{array}{c}\mathbf{0 . 5 8 1} * * * \\
{[8.42]}\end{array}$ \\
\hline LnNAS & $\begin{array}{c}0.127 * * * \\
{[9.08]}\end{array}$ & $\begin{array}{c}0.132 * * * \\
{[9.23]}\end{array}$ & $\begin{array}{c}0.131 * * * \\
{[9.20]}\end{array}$ & $\begin{array}{c}0.125^{* * *} \\
{[8.90]}\end{array}$ & $\begin{array}{c}0.117 * * * \\
{[7.49]}\end{array}$ \\
\hline OPINION & $\begin{array}{c}0.194 * * * \\
{[3.12]}\end{array}$ & $\begin{array}{c}0.193 * * * \\
{[3.09]}\end{array}$ & $\begin{array}{c}0.182 * * * \\
{[2.90]}\end{array}$ & $\begin{array}{c}0.200 * * * \\
{[3.20]}\end{array}$ & $\begin{array}{c}0.173 * * * \\
{[2.59]}\end{array}$ \\
\hline LnASSETS & $\begin{array}{c}0.325^{* * *} \\
{[16.64]}\end{array}$ & $\begin{array}{c}0.327 * * * \\
{[16.74]}\end{array}$ & $\begin{array}{c}0.327 * * * \\
{[16.71]}\end{array}$ & $\begin{array}{c}0.318^{* * * *} \\
{[16.40]}\end{array}$ & $\begin{array}{c}0.319 * * * \\
{[14.92]}\end{array}$ \\
\hline DEBT & $\begin{array}{l}0.205 \\
{[1.29]}\end{array}$ & $\begin{array}{l}0.160 \\
{[1.01]}\end{array}$ & $\begin{array}{l}0.192 \\
{[1.22]}\end{array}$ & $\begin{array}{l}0.183 \\
{[1.16]}\end{array}$ & $\begin{array}{l}0.163 \\
{[0.92]}\end{array}$ \\
\hline REC & $\begin{array}{l}0.056 \\
{[1.04]}\end{array}$ & $\begin{array}{l}0.068 \\
{[1.22]}\end{array}$ & $\begin{array}{l}0.064 \\
{[1.16]}\end{array}$ & $\begin{array}{l}0.068 \\
{[1.26]}\end{array}$ & $\begin{array}{l}0.059 \\
{[0.97]}\end{array}$ \\
\hline INV & $\begin{array}{c}0.610^{* *} \\
{[2.46]}\end{array}$ & $\begin{array}{c}0.580 * * \\
{[2.30]}\end{array}$ & $\begin{array}{c}0.580 * * \\
{[2.29]}\end{array}$ & $\begin{array}{c}0.585^{* *} \\
{[2.36]}\end{array}$ & $\begin{array}{c}0.649 * * \\
{[2.31]}\end{array}$ \\
\hline ACCR & $\begin{array}{l}-0.012 \\
{[-0.23]}\end{array}$ & $\begin{array}{l}-0.003 \\
{[-0.07]}\end{array}$ & $\begin{array}{l}-0.009 \\
{[-0.18]}\end{array}$ & $\begin{array}{l}-0.01 \\
{[-0.19]}\end{array}$ & $\begin{array}{l}-0.01 \\
{[-0.19]}\end{array}$ \\
\hline ROA & $\begin{array}{c}-0.196^{* * *} \\
{[-4.40]}\end{array}$ & $\begin{array}{c}-0.189 * * * \\
{[-4.27]}\end{array}$ & $\begin{array}{c}-0.192 * * * \\
{[-4.31]}\end{array}$ & $\begin{array}{c}-0.188 * * * \\
{[-4.30]}\end{array}$ & $\begin{array}{c}-0.192 * * * \\
{[-4.03]}\end{array}$ \\
\hline LOSS & $\begin{array}{c}-0.256 * * * \\
{[-4.17]}\end{array}$ & $\begin{array}{c}-0.255^{* * * *} \\
{[-4.12]}\end{array}$ & $\begin{array}{c}-0.251 * * * \\
{[-4.07]}\end{array}$ & $\begin{array}{c}-0.259 * * * \\
{[-4.25]}\end{array}$ & $\begin{array}{c}-0.275^{* * * *} \\
{[-4.27]}\end{array}$ \\
\hline QUICK & $\begin{array}{c}-0.008 * * * \\
{[-4.21]}\end{array}$ & $\begin{array}{c}-0.009 * * * \\
{[-4.18]}\end{array}$ & $\begin{array}{c}-0.009 * * * \\
{[-4.54]}\end{array}$ & $\begin{array}{c}-0.009 * * * \\
{[-4.19]}\end{array}$ & $\begin{array}{c}-0.010 * * * \\
{[-4.32]}\end{array}$ \\
\hline SUB & $\begin{array}{c}0.291 * * * \\
{[5.07]}\end{array}$ & $\begin{array}{c}0.302 * * * \\
{[5.20]}\end{array}$ & $\begin{array}{c}0.296^{* * * *} \\
{[5.10]}\end{array}$ & $\begin{array}{c}0.295^{* * * *} \\
{[5.17]}\end{array}$ & $\begin{array}{c}0.280 * * * \\
{[4.53]}\end{array}$ \\
\hline GEOSUB & $\begin{array}{c}0.192^{* * *} \\
{[3.13]}\end{array}$ & $\begin{array}{c}0.166 * * * \\
{[2.66]}\end{array}$ & $\begin{array}{c}0.167 * * * \\
{[2.71]}\end{array}$ & $\begin{array}{c}0.188 * * * \\
{[3.07]}\end{array}$ & $\begin{array}{c}0.216 * * * \\
{[3.29]}\end{array}$ \\
\hline YE & $\begin{array}{l}0.008 \\
{[0.12]} \\
\end{array}$ & $\begin{array}{l}0.027 \\
{[0.39]} \\
\end{array}$ & $\begin{array}{l}0.022 \\
{[0.31]} \\
\end{array}$ & $\begin{array}{l}0.013 \\
{[0.19]} \\
\end{array}$ & $\begin{array}{l}0.015 \\
{[0.21]} \\
\end{array}$ \\
\hline Industry fixed effects & Controlled & Controlled & Controlled & Controlled & Controlled \\
\hline Observations & 1,085 & 1,085 & 1,085 & 1085 & 930 \\
\hline R-squared & 0.78 & 0.78 & 0.78 & 0.79 & 0.79 \\
\hline Adj. R-squared & 0.77 & 0.77 & 0.77 & 0.78 & 0.78 \\
\hline
\end{tabular}

\section{CONCLUSION}

The main objective of this study is to infer the existence of fee premium enjoyed by the auditors, more specifically, who are industry specialist auditors (e.g., city-level, national-level, or jointly specialists). Prior research shows that auditors who are jointly 
specialists (city-and national-level) enjoy premium over other non-specialist auditors or individually either city-level or national-level ISP. However, this study found that industry specialists who are either at city-level or national -level enjoy audit fee premium. This study also documents that auditors who are jointly specialists earn comparatively higher audit fee premium relating to auditors who are individually either city-level specialists or national-level industry specialists. In addition, this study runs sensitivity analysis by excluding small cities (e.g., Adelaide and Brisbane) to see whether base line regression results change due to outlier impact or smaller market impact.

The main results do not change after incorporating above change in sample size, which suggests that the regression models do not suffer any limitation or outlier impact issues. This study complements prior research by documenting audit fees premium are not only enjoyed by city-level rather national-level ISP also enjoy these benefits. This finding suggests that national-level ISP auditors also developed themselves to cope up the changing environment. Another reason for variation of results is the significant changes in accounting regulations environment in Australia. Australia has adopted IFRS from 2005 in line with the UK, which brings a big change in financial reporting environment in Australia, which can also affect the audit fees environment in Australia. This opportunity creates potential avenue for future research.

Finally, I also acknowledge some limitations of this study. First, this study does not calculate complexity associated with IFRS which can increase audit complexity that can be investigated in future research. Second, this study does not calculate the changes in audit fees pre-and post-IFRS adoption, which can provide a better picture to understand if there is any impact of IFRS adoption on increasing audit fees. Third, this study is based on only one-year data, which requires caution to generalize its findings. Future research can overcome such limitations. Overall, the present study can attract attention of financial statement preparers, investors, and other regulatory bodies by providing empirical results on audit fee premiums which very crucial and widely researched in different contexts.

\section{REFERENCES}

Audousset-Coulier, S., Jeny, A., \& Jiang, L. (2016). The validity of auditor industry specialization measures. Auditing: A Journal of Practice \& Theory, 35(1), 139-161.

Basioudis, I. G., \& Francis, J. R. (2007). Big 4 audit fee premiums for national and office-level industry leadership in the United Kingdom. Auditing: A Journal of Practice \& Theory, 26(2), 143-166.

Bell, T., Marrs, F., Solomon, I., \& Thomas, H. (1997). Auditing organisations through a strategic-systemetn lens: The KPMG business measurement process. Montvale, N. J.: KPMG Peat Marwick.

Cahan, S. F., Jeter, D. C., \& Naiker, V. (2011). Are all industry specialist auditors the same? Auditing: A Journal of Practice \& Theory, 30(4), 191-222.

Casterella, J. R., Francis, J. R., Lewis, B. L., \& Walker, P. L. (2004). Auditor industry specialization, client bargaining power, and audit pricing. Auditing: A Journal of Practice \& Theory, 23(1), 123-140.

Craswell, A. T., Francis, J. R., \& Taylor, S. L. (1995). Auditor brand name reputations and industry specializations. Journal of Accounting \& Economics, 20(3), 297-322.

De George, E. T., Ferguson, C. B., \& Spear, N. A. (2013). How much does IFRS cost? IFRS adoption and audit fees. The Accounting Review, 88(2), 429-462. 
DeFond, M. L., Francis, J. R., \& Wong, T. J. (2000). Auditor industry specialization and market segmentation: Evidence from Hong Kong. Auditing: A Journal of Practice \& Theory, 19(1), 49-66.

Ettredge, M. L., Yang, X., \& Yi, H. S. (2014). Fair value measurements and audit fees: Evidence from the banking Industry. Auditing: A Journal of Practice \& Theory, 33(3), 33-58.

Ferguson, A. C., Francis, J. R., \& Stokes, D. J. (2006). What matters in audit pricing: Industry specialization or overall market leadership? Accounting \& Finance, 46(1), 97-106.

Ferguson, A., \& Stokes, D. (2002). Brand name audit pricing, industry specialization, and leadership premiums post-big 8 and big 6 mergers. Contemporary Accounting Research, 19(1), 77-110.

Ferguson, A., Francis, J. R., \& Stokes, D. J. (2003). The effects of firm-wide and officelevel industry expertise on audit pricing. The Accounting Review, 78(2), 429-448.

Francis, J. R., Kenneth, R., \& Wang, D. (2005). The pricing of national and city-specific reputations for industry expertise in the U.S. audit market. The Accounting Review, 80(1), 113-136.

GAO, G. A. O. (2003). Public accounting firms: Mandated study on consolidation and competition. Washington, D. C.: Government Printing Office.

GAO, G. A. O. (2008). Auditors of public companies: Continued concentration in audit market for large public companies does not call for immediate action. Washington, D. C.: Government Printing Office.

Hua-Wei, H., Li-Lin, L., Raghunandan, K., \& Rama, D. V. (2007). Auditor industry specialization, client bargaining power, and audit fees: Further evidence. Auditing: A Journal of Practice \& Theory, 26(1), 147-158.

Lawrence, A., Minutti-Meza, M., \& Zhang, P. (2011). Can big 4 versus non-big 4 differences in audit-quality proxies be attributed to client characteristics? The Accounting Review, 86(1), 259-286.

Low, K. -Y. (2004). The effects of industry specialization on audit risk assessments and audit-planning decisions. The Accounting Review, 79(1), 201-219.

Miah, M. S. (2017). Accounting standards complexity, audit fees and financial analyst forecasts in Australia. Doctoral dissertation in Accounting at Massey University, Albany, New Zealand.

Miah, M. S. (2019). Fair value, management discretion, and audit fees: An empirical analysis. Journal of Corporate Accounting \& Finance, 30(2), 82-91.

Reichelt, K. J., \& Wang, D. (2010). National and office-specific measures of auditor industry expertise and effects on audit quality. Journal of Accounting Research, 48(3), 647-686.

Taylor, M. H. (2000). The effects of Industry specialization on auditors' inherent risk assessments and confidence judgements. Contemporary Accounting Research, 17(4), 693-712. 